\title{
Value of different methods for the characterisation of Aspergillus terreus strains
}

\author{
P.-M. RATH, STEPHANIE KAMPHOFF and R. ANSORG \\ Institut für Medizinische Mikrobiologie, Universität-GH Essen, Hufelandstrasse 55, D-45147 Essen, Germany
}

\begin{abstract}
To evaluate different methods for strain differentiation, 10 isolates of Aspergillus terreus from Germany and two epidemiologically unrelated strains were investigated. The sources of the isolates were patients with cystic fibrosis (4), immunosuppression (2), otitis externa (2), sinusitis (1) and endocarditis (1). Environmental isolates were obtained from a contaminated cell culture and from soil. The isolates did not differ in their macroscopic and microscopic morphology, in their protein patterns analysed by SDSPAGE and in their susceptibility to amphotericin B and itraconazole. The RFLP analysis of total genomic DNA digested by EcoRI resulted in patterns that were too faint for interpretation. However, after hybridisation of the digested DNA with a short DNA probe of repetitive sequence, six different patterns were found. Based on the patterns of the randomly amplified polymorphic DNA (RAPD) with three primers, nine different genotypes were discriminate. RAPD patterns discriminated the epidemiologically unrelated reference strains (endocarditis isolate from Thailand, soil isolate from the USA) and the isolates from Germany. It is concluded that, in contrast to the phenotypic methods, the analysis of RAPD patterns is useful for strain differentiation of $A$. terreus.
\end{abstract}

\section{Introduction}

Members of the genus Aspergillus are opportunist pathogens [1]. Most infections in man occur in severely immunocompromised patients [2]. A. fumigatus represents the most common agent of systemic infections, followed by $A$. flavus [2]. A. terreus is widespread in the environment, particularly in soil and on decaying vegetation [1]. It has also been found in the air of hospital areas [3,4]. Invasive infections in man and animals have been reported [5,7-11], showing that $A$. terreus is not simply a colonising organism. A nosocomial outbreak of invasive aspergillosis caused by this species has been described [12].

Various phenotypic and genotypic methods have been used successfully in fingerprinting $A$. fumigatus. Analysis of protein patterns by SDS-PAGE and immunoblotting were used for phenotypic fingerprinting $[13,14]$. The analysis of restriction fragment length polymorphism (RFLP) $[15,16]$ patterns after hybridisation with probes of moderately repetitive sequences $[17,18]$ and the patterns resulting from

Received 11 Feb. 1998; revised version accepted 30 May 1998.

Corresponding author: Dr P.-M. Rath. random amplification of polymorphic DNA (RAPD) were used for genotypic fingerprinting [19-24]. However, no comparable data are available for $A$. terreus.

To gain information on the typability of $A$. terreus, 12 isolates were investigated by the following methods: (i) macroscopic and microscopic morphology; (ii) susceptibility to amphotericin B and itraconazole; (iii) protein patterns in SDS-PAGE; (iv) DNA patterns after hybridisation of EcoRI-digested genomic DNA; and (v) DNA patterns resulting from RAPD-PCR.

\section{Materials and methods}

\section{A. terreus isolates}

The sources of isolates are listed in Table 1. Nine isolates (nos. 1-9) were from seven patients at the University Hospital of Essen, Germany. Paired isolates were obtained from sputum samples of two patients (A, B) with cystic fibrosis. Isolate no. 11 was found in a contaminated cell culture of eukaryotic cells at the University Hospital of Essen. Two isolates were from the Centraalbureau voor Schimmelcultures (CBS, Baarn and Delft, the Netherlands). One isolate (no. 10) was found on a cardiac valve of a patient with endocarditis who lived in Thailand (CBS 116.46). The other isolate (no. 12) was a soil isolate from the USA 
Table 1. A. terreus isolates: sources, susceptibility testing, RAPD and hybridisation types

\begin{tabular}{|c|c|c|c|c|c|c|c|c|c|c|}
\hline \multirow[b]{2}{*}{$\begin{array}{l}\text { Strain } \\
\text { No. }\end{array}$} & \multirow[b]{2}{*}{ Source } & \multirow[b]{2}{*}{ Patient } & \multirow{2}{*}{$\begin{array}{l}\text { Underlying } \\
\text { condition }\end{array}$} & \multirow{2}{*}{$\begin{array}{l}\text { Date of } \\
\text { isolation }\end{array}$} & \multicolumn{2}{|c|}{$\mathrm{MIC}$ of $\mathrm{AmB}^{*}$} & \multicolumn{3}{|c|}{ RAPD type ${ }^{\dagger}$} & \multirow{2}{*}{$\begin{array}{l}\text { Hybridisation } \\
\text { type }\end{array}$} \\
\hline & & & & & $48 \mathrm{~h}$ & $72 \mathrm{~h}$ & $\mathrm{P} 1$ & $\mathrm{P} 2$ & P3 & \\
\hline 1 & Sputum & A & Cystic fibrosis & $31 / 7 / 1995$ & 2 & 32 & I & I & $\mathrm{I}$ & A \\
\hline 2 & Sputum & A & Cystic fibrosis & $26 / 4 / 1996$ & 2 & 32 & I & $I$ & $\mathrm{I}$ & A \\
\hline 3 & Sputum & $\mathrm{B}$ & Cystic fibrosis & $10 / 10 / 1996$ & 0.5 & 32 & II & II & II & B \\
\hline 4 & Sputum & B & Cystic fibrosis & $13 / 11 / 1996$ & 1 & 16 & II & II & II & B \\
\hline 5 & Sputum & $\mathrm{C}$ & Immunosuppression & $13 / 8 / 1993$ & 8 & $>64$ & $\mathrm{I}$ & I & I & A \\
\hline 6 & Tracheal secretion & $\mathrm{D}$ & Immunosuppression & $3 / 11 / 1994$ & 8 & 16 & III & III & I & A \\
\hline 7 & External ear & $\mathrm{E}$ & Otitis externa & $1 / 3 / 1994$ & 2 & 4 & III & IV & III & B \\
\hline 8 & External ear & $\mathrm{F}$ & Otitis externa & $26 / 8 / 1995$ & 2 & $>64$ & VI & $\mathrm{V}$ & VI & $\mathrm{C}$ \\
\hline 9 & Sinus maxillaris & $\mathrm{G}$ & Sinusitis & $28 / 9 / 1995$ & 2 & 4 & V & VI & V & C \\
\hline $10^{\ddagger}$ & Cardiac valve & $\mathrm{H}$ & Endocarditis & No data & 2 & 4 & VI & VII & VI & $\mathrm{D}$ \\
\hline 11 & Cell culture & - & - & $12 / 4 / 1996$ & 4 & 64 & VII & VIII & VII & $\mathrm{E}$ \\
\hline $12^{\ddagger}$ & Soil & - & - & No data & 1 & 2 & VIII & IX & VIII & $\mathrm{F}$ \\
\hline
\end{tabular}

${ }^{*} \mathrm{MIC}$ of amphotericin $\mathrm{B}(\mathrm{AmB})$ in $\mathrm{mg} / \mathrm{l}$.

${ }^{\dagger} \mathrm{P} 1, \mathrm{P} 2, \mathrm{P} 3$; number of primer.

${ }^{\ddagger}$ Culture collection strains (CBS)

(CBS 469.81). The isolates from Essen were subcultured no more than five times before analysis.

\section{Macroscopic and microscopic morphology}

For species identification and investigation of the macroscopic and microscopic morphology, single spot cultures were performed on Czapek Solution Agar (Difco) and Malt Extract Agar (Difco). Cultures were incubated for 10 days at room temperature. The microscopic examination was performed on colonies grown on malt extract agar. The production of aleuriospores (globose to cavate hyaline cells produced on the vegetative submerged mycelium [5]) was investigated by microscopic examination of the reverse side of the culture plates at a magnification of 600 .

\section{Susceptibility testing}

For determination of susceptibility to amphotericin B (amphotericin B/deoxycholate; Squipp-von Heyden, Munich, Germany) and itraconazole (Janssen, Olen, Belgium), micro-dilution broth assays with RPMI-1640 (with L-glutamine, without sodium bicarbonate; Sigma) buffered with $0.165 \mathrm{M}$ MOPS (Sigma) were performed as described previously [25]. The range of the final concentrations in the tests was $0.125-128 \mathrm{mg} / \mathrm{L}$ for amphotericin B and $0.015-8 \mathrm{mg} / \mathrm{L}$ for itraconazole. Each well contained $c .10^{4} \mathrm{cfu}$ in a final volume of $200 \mu \mathrm{l}$. One well without an antimycotic agent served as growth control. The plates were incubated at $35^{\circ} \mathrm{C}$ and the MICs were determined after incubation for $48 \mathrm{~h}$. The MICs of amphotericin B were also determined after incubation for $72 \mathrm{~h}$. The MIC for itraconazole was defined as the lowest concentration that inhibited c. $75 \%$ of growth compared to the growth control $[25,26]$. For amphotericin B, the MIC was fixed at the lowest concentration with no visible growth $[25,26]$. All experiments were performed twice. $A$. fumigatus ATCC 90906 with published MIC values for amphotericin B and itraconazole [27] was tested in parallel in each test series.

\section{$S D S-P A G E$}

The isolates were cultured on Sabouraud Glucose Agar (Unipath) at $33^{\circ} \mathrm{C}$ for 3 days. Conidia were harvested by swabbing and suspended in distilled water; c. $10^{6}$ conidia were suspended in $250 \mathrm{ml}$ of Sabouraud Glucose Broth (Unipath). The suspensions were cultured on an orbital shaker $(150 \mathrm{rpm})$ at $33^{\circ} \mathrm{C}$ for $72 \mathrm{~h}$. Mycelia were harvested by filtration with Miracloth (Calbiochem, La Jolla, CA, USA) and were washed three times with $\mathrm{NaCl} 0.9 \%$ solution followed by a washing step in Tris-HCl-EDTA buffer $(0.1 \mathrm{M}$ Tris- $\mathrm{HCl}, \mathrm{pH} 7.5,0.01 \mathrm{M}$ EDTA) containing $5 \mu \mathrm{g} / \mathrm{ml}$ (Boehringer Mannheim, Germany) and $0.01 \mathrm{M}$ PMSF (Sigma). A 5-ml X-press chamber (Bachhofer, Reutlingen, Germany) was loaded with $c .8 \mathrm{~g}$ (wet weight) of the mycelial mass and was frozen at $-20^{\circ} \mathrm{C}$ overnight. The cells were disrupted by pressing the frozen mycelium four times (pressure 1-1.5 $\mathrm{t}$ ). This procedure resulted in $c .90 \%$ cell disruption, as determined by microscopic control. After thawing and centrifugation $\left(10000 \mathrm{~g}, 4^{\circ} \mathrm{C}, 20 \mathrm{~min}\right)$, the protein content of the clear supernates was determined by a modified Lowry assay (Pierce, Rockford, IL, USA). After boiling samples of the suspensions with an equal volume of buffer $(0.125 \mathrm{M}$ Tris- $\mathrm{HCl}, \mathrm{pH} 6.8$, SDS $4 \%$, glycerol $20 \%$, 2-mercaptoethanol $10 \%$ ), samples containing $20 \mu \mathrm{g}$ of protein were loaded on to $12.5 \%$ and $7.5 \%$ continuous SDS-polyacrylamide gels. Marker proteins (Promega, Madison, USA; Gibco, Eggenstein, Germany) were run in parallel. After electrophoresis, the gels were stained with Coomassie Blue (Serva, Heidelberg, Germany).

\section{Preparation of DNA}

The method of preparation of DNA was identical to that described previously [24]. Briefly, strains were cultured on Sabouraud glucose agar for $72 \mathrm{~h}$ at $33^{\circ} \mathrm{C}$. Conidia were harvested by swabbing and inoculated in to five petri dishes (diameter $9.5 \mathrm{~cm}$ ), containing $5 \mathrm{ml}$ of Sabouraud glucose broth (Unipath) each. Cultures were incubated for $24 \mathrm{~h}$ at $33^{\circ} \mathrm{C}$. The mycelial cells were harvested, washed and disrupted by vortex mixing 
with glass beads at maximal speed. The DNA was isolated by phenol-chloroform extraction and precipitation in ammonium acetate and ethanol. The concentrations of DNA were determined, after digestion of RNA, by the DNA DipStick (Invitrogen, Leek, the Netherlands).

\section{RFLP and hybridisation}

DNA (c. $200 \mathrm{ng}$ ) was digested with EcoRI (Boehringer Mannheim) and applied to an agarose $1 \%$ gel. After electrophoresis in TAE $(40 \mathrm{mM}$ Tris acetate, $2 \mathrm{mM}$ EDTA) the gels were stained with ethidium bromide. The DNA fragments were transferred to a nylon membrane (Boehringer Mannheim) and hybridised with digoxigenin-labelled DNA-probe $\left(5^{\prime}-(\mathrm{GTG})_{5}-3^{\prime}\right)$ at $45^{\circ} \mathrm{C}$ overnight in hybridisation buffer and detected as recommended by the manufacturers of the DIG Luminescent Detection Kit (Boehringer Mannheim). The membranes were placed on X-ray films (X-OMAT AR, Eastman Kodak, Rochester, NY, USA) for $3 \mathrm{~h}$ at $37^{\circ} \mathrm{C}$.

\section{$R A P D-P C R$}

The primers used for polymerase chain reaction (PCR) were synthesised by MWG-Biotech (Ebersberg, Germany). Primer 1 (R108, 5'-GTATTGCCCT-3') was described by Aufauvre-Brown et al. [19]. The sequence of primer 2 (5'-GCTGGTGG-3') was published by Loudon et al. [22]. The sequence of primer 3 was $5^{\prime}-$ TCACCCTGA-3' [24]. DNA was amplified with the single primers and pairwise combinations of primers as described previously [24]. Briefly, amplification was performed in a mastermix $\left(50 \mathrm{mM} \mathrm{KCl}, 3 \mathrm{mM} \mathrm{MgCl}_{2}\right.$, $10 \mathrm{mM}$ Tris- $\mathrm{HCl}, \mathrm{pH} 8.8$ ) containing $200 \mathrm{mM}$ (each) of dATP, dCTP, dGTP and dTTP (Biozym Diagnostik, Oldenburg, Germany), $1 \mu \mathrm{g}$ of primer, $2.5 \mathrm{U}$ of Taq DNA Polymerase (Promega, Madison, USA) and $5 \mu \mathrm{l}$ $(1 \mu \mathrm{g} / \mu \mathrm{l})$ of template DNA in a final volume of $100 \mu 1$. A Minicycler (MJ Research, Watertown, USA) was used. After an initial cycle $\left(94^{\circ} \mathrm{C} 5 \mathrm{~min}, 35^{\circ} \mathrm{C}\right.$ $\left.2 \mathrm{~min}, 72^{\circ} \mathrm{C} 2 \mathrm{~min}\right) 45$ cycles of amplification $\left(94^{\circ} \mathrm{C}\right.$ $1 \mathrm{~min}, 35^{\circ} \mathrm{C} 2 \mathrm{~min}, 72^{\circ} \mathrm{C} 2 \mathrm{~min}$ ) were followed by a final extension at $72^{\circ} \mathrm{C}$ for $10 \mathrm{~min}$. All primers were run under the same conditions. The amplified products were electrophoresed at $100 \mathrm{~V}$ in a horizontal agarose $1.6 \%$ gel. Gels were photographed after staining with ethidium bromide. A mol.-wt marker (Pharmacia, Uppsala, Sweden) was run in parallel. RAPD patterns were compared visually. An isolate was defined as different when a band with a density equal to or greater than that of the $0.8-\mathrm{kb}$ band of the marker (reference density) occurred and no corresponding band (not even a trace) was detectable in the other isolates. To demonstrate reproducibility of the patterns, all isolates were investigated three times independently, with different subcultures.

\section{Results}

\section{Morphology}

The $12 \mathrm{~A}$. terreus isolates did not differ in their macroscopic and microscopic morphology on Czapek solution agar and malt extract agar. Colonies of all isolates exhibited a cinnamon-brown colour on Czapek solution agar and a wood-brown colour on malt extract agar. All isolates produced aleuriospores on both media. A brown exudate was produced on Czapek solution agar, but not on malt extract agar.

\section{Susceptibility to amphotericin B and itraconazole}

In susceptibility testing with amphotericin B, the MIC values of the $A$. fumigatus control strain remained constant at $0.25-0.5 \mathrm{mg} / \mathrm{L}$ during the $72-\mathrm{h}$ incubation period. However, the MIC values of the A. terreus isolates increased from 0.5 to $8 \mathrm{mg} / \mathrm{L}$ after $48 \mathrm{~h}$ to $2->64 \mathrm{mg} / \mathrm{L}$ after incubation for $72 \mathrm{~h}$. The MIC range against itraconazole was $0.03-0.125 \mathrm{mg} / \mathrm{L}$ after $48 \mathrm{~h}$.

\section{Protein patterns in SDS-PAGE}

All isolates showed identical protein patterns in SDSPAGE with numerous bands in the range $14-120 \mathrm{kDa}$. Major bands were seen at 20, 22, 26, 39, 53, 60, 78, 95 and $100 \mathrm{kDa}$.

\section{RFLP and hybridisation patterns}

The EcoRI-RFLP of cellular DNA resulted in numerous bands. The patterns were too faint for interpretation. However, after hybridisation with the DNA-probe $5^{\prime}-(\mathrm{GTG})_{5}-3^{\prime}$, six distinct patterns could be separated (Fig. 1 and Table 1). The isolates from patients A, C and $\mathrm{D}$ showed identical patterns (hybridisation type A), as did the isolates from patients $\mathrm{B}$ and $\mathrm{E}$ (hybridisation type B) and the isolates from patients $F$ and $G$ (hybridisation type $\mathrm{C}$ ). The remaining isolates showed different patterns.

\section{Patterns in RAPD}

Further discrimination was obtained by RAPD analysis (Table 1). With primers 1 and 3, respectively, the 12 isolates could be discriminated into eight RAPD types. Primer 2 showed further discrimination, resulting in nine RAPD types (Fig. 2). The isolates from patients $B$ and $\mathrm{E}, \mathrm{C}$ and $\mathrm{D}$, and $\mathrm{F}$ and $\mathrm{G}$, respectively, could be discriminated from each other. In agreement with the hybridisation results, the paired isolates of patients $A$ and $\mathrm{B}$, respectively, were identical (RAPD type I and II). All German isolates showed a band at $770 \mathrm{bp}$ with primer 2 which did not occur in the epidemiologically unrelated reference strains (nos. 10 and 12). The RAPD with pairwise combined primers resulted in no further discrimination. No differences in band patterns were found when testing different subcultures. 


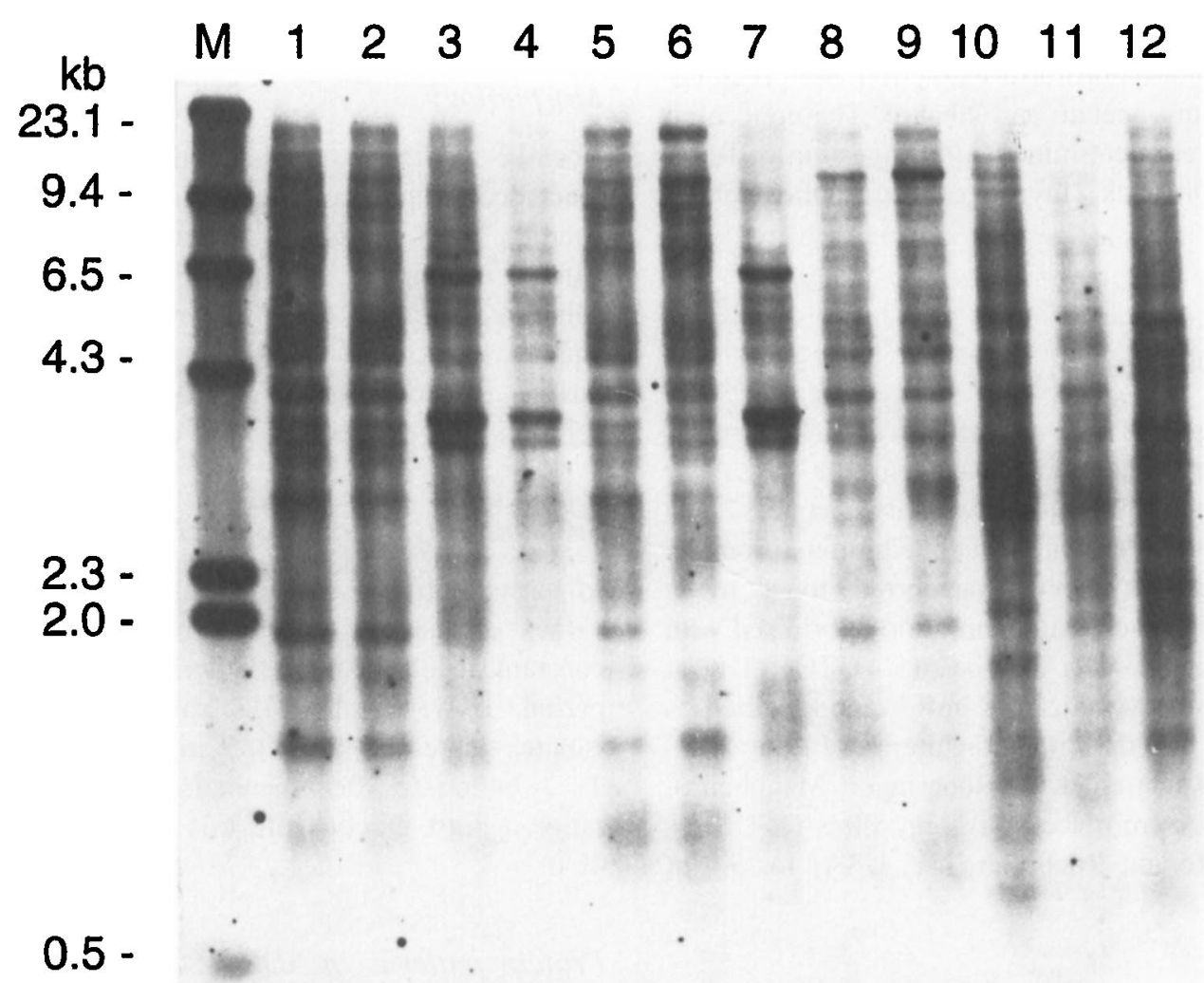

Fig. 1. Hybridisation patterns of $12 \mathrm{~A}$. terreus isolates. The lane numbers represent the isolate numbers in Table 1. The mol. wts of marker bands (M) are given on the left side.
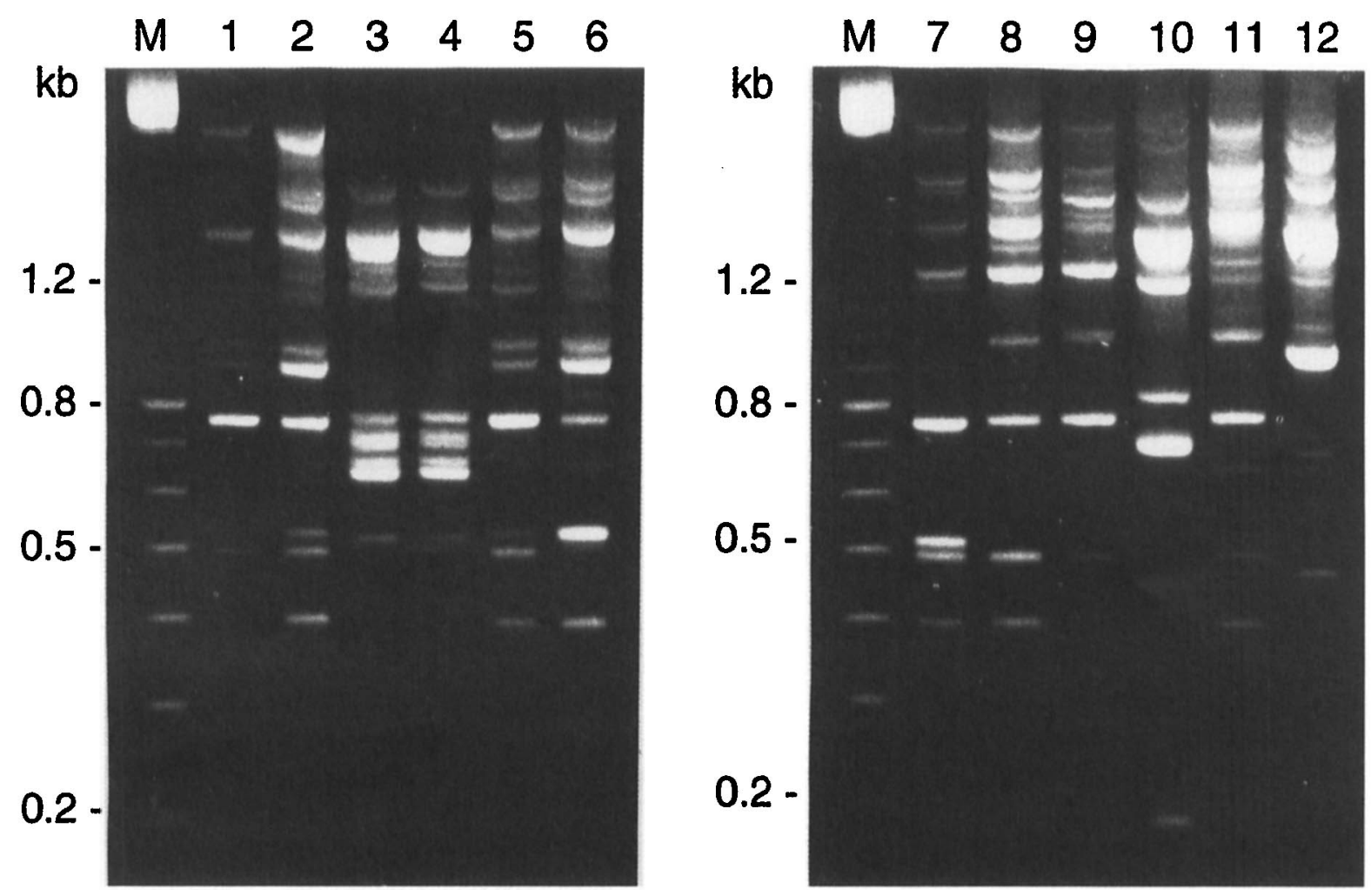

Fig. 2. RAPD patterns of $12 \mathrm{~A}$. terreus isolates produced by primer $2(1.6 \%$ agarose gel). The lane numbers represent the isolate numbers in Table 1 . The mol.wts of the marker bands $(M)$ are given on the left side. Isolates 1 and 2 showed identical patterns in the original picture. 


\section{Discussion}

To our knowledge, this is the first study of $A$. terreus with different methods for strain differentiation. No differences were found in the macroscopic and microscopic morphology of the $12 \mathrm{~A}$. terreus isolates. All isolates produced aleuriospores, which are not only found in $A$. terreus, but also in A. flavipens (white colonies), A. niveus and $A$. carneus [28]. However, no hülle cells, characteristic for $A$. flavipens and $A$. carneus [28], were found in the isolates under investigation.

In susceptibility testing a time-dependent increase of MICs for amphotericin B up to $>64 \mathrm{mg} / \mathrm{L}$ was found. As the MIC values of the $A$. fumigatus reference strain remained constant over the incubation period of $72 \mathrm{~h}$, no systematic error occurred. Similar results have been found by others [29]. The high MIC values of amphotericin B after prolonged incubation may have implications for the treatment of $A$. terreus infections. All isolates showed MIC values of $0.03-0.125 \mathrm{mg} / \mathrm{L}$ for itraconazole after incubation for $48 \mathrm{~h}$. Therefore, susceptibility testing does not seem to be useful for strain differentiation. In studies on $A$. fumigatus strain-specific differences were found in SDS-PAGE protein patterns [13]. In contrast, no differences in SDS-PAGE were found in another study; however, only a few strains of this species were investigated [24]. In the present study, all isolates of $A$. terreus showed identical protein patterns in SDS-PAGE. Therefore, the analysis of protein patterns is not useful for strain differentiation in $A$. terreus.

Based on the results of the oligoblot hybridisation, six different patterns could be discriminated. However, interpretation of the patterns was difficult because of the numerous bands obtained by this method. RAPD analysis showed greater discrimination, resulting in nine different genotypes. Previously, this technique was used successfully in fingerprinting other Aspergillus species [19-24], showing a high genetic diversity in A. fumigatus and A. flavus. Similar results were also found for $A$. terreus in the present study. Therefore, RAPD seems to provide the best discriminatory power, i.e., the ability to demonstrate diversity within a species.

Both the epidemiologically unrelated reference strains could be separated from the German isolates based on the RAPD patterns with one primer. However, only a limited number of isolates was investigated in the present study and conclusions on the correlation of a specific RAPD pattern to the epidemiological origin of a strain could not be drawn. It is necessary to investigate epidemiologically unrelated outbreak strains to answer this important question. Unfortunately, no such strains of $A$. terreus exist in culture collections, i.e., NCPF, ATCC or CBS.
In both patients with cystic fibrosis, the paired isolates were genetically identical. These results indicate that this method is potentially useful in the analysis of nosocomial outbreaks of aspergillosis caused by $A$. terreus. However, the RAPD method is subject to some limitations. The reproducibility of patterns in one laboratory under the same experimental conditions is excellent, as described here. However, it has been reported that patterns depend on the Taq polymerases and the cycler used [30], indicating that the reproducibility of patterns between laboratories might be problematic. Therefore, there is an urgent need for inter-laboratory standardisation of this technique.

We thank D. Schmidt for excellent technical assistance.

\section{References}

1. Kwon-Chung KJ, Bennett JE. Medical mycology. Philadelphia, Lea and Febinger. 1992.

2. Bodey GP, Vartivarian S. Aspergillosis. Eur J Clin Microbiol Infect Dis 1989; 8: 413-437.

3. Goodley JM, Clayton YM, Hay RJ. Environmental sampling for aspergilli during building construction on a hospital site. $J$ Hosp Infect 1994; 26: 27-35.

4. Noble WC, Clayton YM. Fungi in the air of hospital wards. $J$ Gen Microbiol 1963; 32: 397-402.

5. de Hoog GS, Guarro J. Atlas of clinical fungi. Centraalbureau voor Schimmelcultures, University Rovira i Virgili, Baarn and Delft, the Netherlands and Reus, Spain. 1995.

6. Hagensee ME, Bauwens JE, Kjos B, Bowden RA. Brain abscess following marrow transplantation: experience at the Fred Hutchinson Cancer Research Center, 1984-1992. Clin Infect Dis 1994; 19: 402-408.

7. Tritz DM, Woods GL. Fatal disseminated infection with Aspergillus terreus in immunocompromised hosts. Clin Infect Dis 1993; 16: 118-122.

8. Iwen PC, Reed EC, Armitage JO et al. Nosocomial invasive aspergillosis in lymphoma patients treated with bone marrow or peripheral stem cell transplants. Infect Control Hosp Epidemiol 1993; 14: 131-139.

9. Russack V. Aspergillus terreus myocarditis: report of a case and review of the literature. Am J Cardiovasc Pathol 1990; 3: 275-279.

10. Watt PR, Robins GM, Galloway AM, O'Boyle DA. Disseminated opportunistic fungal disease in dogs: 10 cases (19821990). J Am Vet Med Assoc 1995; 207: 67-70.

11. Knudtson WU, Kirkbride CA. Fungi associated with bovine abortion in the northern plains states (USA). $J$ Vet Diagn Invest 1992; 4: 181-185.

12. Flynn PM, Williams BG, Hetherington SV, Williams BF, Giannini MA, Pearson TA. Aspergillus terreus during hospital renovation. Infect Control Hosp Epidemiol 1993; 14: 363-365.

13. Burnie JP, Matthews RC, Clark I, Milne LJR. Immunoblot fingerprinting Aspergillus fumigatus. J Immunol Methods 1989; 118: $179-186$.

14. Symoens F, Viviani MA, Nolard N. Typing by immunoblot of Aspergillus fumigatus from nosocomial infections. Mycoses 1993; 36: 229-237.

15. Burnie JP, Coke A, Matthews RC. Restriction endonuclease analysis of Aspergillus fumigatus DNA. J Clin Pathol 1992; 45: $324-327$.

16. Denning DW, Clemons KV, Hanson LH, Stevens DA. Restriction endonuclease analysis of total cellular DNA of Aspergillus fumigatus isolates of geographically and epidemiologically diverse origin. $J$ Infect Dis 1990; 162: 1151-1158.

17. Girardin H, Latgé J-P, Srikantha T, Morrow B, Soll DR. Development of DNA probes for fingerprinting Aspergillus fumigatus. J Clin Microbiol 1993; 31: 1547-1554.

18. Girardin H, Sarfati J, Traoré F, Camet JD, Derouin F, Latgé JP. Molecular epidemiology of nosocomial invasive aspergillosis. $J$ Clin Microbiol 1994; 32: 684-690.

19. Aufauvre-Brown A, Cohen J, Holden DW. Use of randomly 
amplified polymorphic DNA markers to distinguish isolates of Aspergillus fumigatus. J Clin Microbiol 1992; 30: 2991-2993.

20. Leenders A, van Belkum A, Janssen $\mathrm{S}$ et al. Molecular epidemiology of apparent outbreak of invasive aspergillosis in a hematology ward. J Clin Microbiol 1996; 34: 345-351.

21. Lin D, Lehmann PF, Hamory $\mathrm{BH}$ et al. Comparison of three typing methods for clinical and environmental isolates of Aspergillus fumigatus. J Clin Microbiol 1995; 33: 1596-1601.

22. Loudon KW, Burnie JP, Coke AP, Matthews RC. Application of polymerase chain reaction to fingerprinting Aspergillus fumigatus by random amplification of polymorphic DNA. $J$ Clin Microbiol 1993; 31: 1117-1121.

23. Mondon P, Thélu J, Lebeau B, Ambroise-Thomas P, Grillot R. Virulence of Aspergillus fumigatus strains investigated by random amplified polymorphic DNA analysis. $J$ Med Microbiol 1995; 42: 299-303.

24. Rath P-M, Marggraf G, Dermoumi H, Ansorg R. Use of phenotypic and genotypic fingerprinting methods in the strain identification of Aspergillus fumigatus. Mycoses 1995; 38: 429-434.
25. Rath P-M. Susceptibility of Aspergillus strains from culture collections to amphotericin B and itraconazole. $J$ Antimicrob Chemother 1998; 41: 567-570.

26. Espinel-Ingroff A, Pfaller MA. Antifungal agents and susceptibility testing. In: Murray PR, Baron EJ, Pfaller MA, Tenover FC, Yolken RH (eds) Manual of Clinical Microbiology. Washington, DC, ASM Press. 1995: 1405-1414.

27. Dermoumi $H$. In vitro susceptibility of fungal isolates of clinically important specimens to itraconazole, fluconazole and amphotericin B. Chemotherapy 1994; 40: 92-98.

28. Raper KB, Fennell DI. The genus Aspergillus. Baltimore, Williams and Wilkins. 1965: 567-577.

29. Singh SM, Sharma S, Chatterjee PK. Clinical and experimental mycotic keratitis caused by Aspergillus terreus and the effect of subconjunctival oxiconazole treatment in the animal model. Mycopathologia 1990; 112: 127-137.

30. Meunier J-R, Grimont PAD. Factors affecting reproducibility of random amplified polymorphic DNA fingerprinting. Res Microbiol 1993; 144: 373-379. 